\title{
Paenibacillus barcinonensis sp. nov., a xylanase- producing bacterium isolated from a rice field in the Ebro River delta
}

Correspondence

F. I. Javier Pastor fpastor@bio.ub.es

\author{
Marta M. Sánchez, ${ }^{1}$ Dagmar Fritze, ${ }^{2}$ Ana Blanco, ${ }^{1}$ Cathrin Spröer, ${ }^{2}$ \\ Brian J. Tindall, ${ }^{2}$ Peter Schumann, ${ }^{2}$ Reiner M. Kroppenstedt, ${ }^{2}$ \\ Pilar Diaz ${ }^{1}$ and F. I. Javier Pastor ${ }^{1}$
}

\author{
${ }^{1}$ Department of Microbiology, Faculty of Biology, University of Barcelona, Avenida Diagonal \\ 645, 08028 Barcelona, Spain \\ ${ }^{2} \mathrm{DSMZ}$ - Deutsche Sammlung von Mikroorganismen und Zellkulturen GmbH, Mascheroder \\ Weg 1b, D-38124, Braunschweig, Germany
}

\begin{abstract}
A Gram-positive, endospore-forming, xylanase-producing bacterium isolated from a rice field was studied taxonomically. The strain grows at $10-40{ }^{\circ} \mathrm{C}$ and in the presence of lysozyme or $5 \%(\mathrm{w} / \mathrm{v}) \mathrm{NaCl}$. Chemotaxonomic analysis revealed that $\mathrm{MK}-7$ was the predominant menaquinone of the isolated strain, while the major fatty acid was anteiso- $\mathrm{C}_{15: 0}$. Comparison of $16 \mathrm{~S}$ rRNA gene sequences showed that strain $\mathrm{BP}-23^{\top}$ fell within the radiation of the cluster comprising Paenibacillus species. The highest 16S rRNA gene sequence similarities were found with Paenibacillus illinoisensis (97.4\%), Paenibacillus pabuli (97.1\%) and Paenibacillus amylolyticus (96.9\%). The DNA-DNA relatedness of strain $B P-23^{\top}$ with respect to these three species was very low $(32 \cdot 7,31 \cdot 6$ and $23 \cdot 0 \%$, respectively). On the basis of phenotypic and genotypic data, strain BP- $23^{\top}$ should be placed in the genus Paenibacillus and designated a novel species, for which the name Paenibacillus barcinonensis sp. nov. is proposed. The type strain is BP $-23^{\top}$ (=CECT $7022^{\top}=$ DSM $15478^{\top}$ ).
\end{abstract}

Members of the genus Bacillus are common saprophytic components of soil microbiota (Claus \& Berkeley, 1986). Some species are known to secrete a variety of extracellular enzymes, several of which have important industrial applications (Outtrup \& Jørgensen, 2002). Genomic analysis of the genus Bacillus, using rRNA-DNA sequencing (Ash et al., 1991), has led to its division into distinct genera. One of these is the genus Paenibacillus (Ash et al., 1993), which comprises rRNA group 3 and includes several longestablished species, such as Paenibacillus polymyxa, Paenibacillus alvei and Paenibacillus macerans, and an increasing number of newly identified species isolated from soil and lignocellulosic materials (Berge et al., 2002). In the present study, the taxonomic status of strain $\mathrm{BP}-23^{\mathrm{T}}$, previously isolated from soil after enrichment culture on rice straw (Blanco \& Pastor, 1993) and selected as a xylanase-producer (Blanco et al., 1995), was analysed.

Published online ahead of print on 12 November 2004 as DOI 10.1099/ijs.0.63383-0.

The GenBank/EMBL/DDBJ accession number for the 16S rRNA gene sequence of strain $B P-23^{\top}$ is $A J 716019$.

Micrographs of sporulating cells of strain $\mathrm{BP}-23^{\top}$ and an extended version of the neighbour-joining tree shown in Fig. 1 are available as supplementary material in IJSEM Online.
Strain $\mathrm{BP}-23^{\mathrm{T}}$ was isolated from soil from a rice field in the delta of the River Ebro (Spain) after enrichment culture at room temperature on rice straw for 2 months (Blanco \& Pastor, 1993). A sample was then suspended in water, incubated at $70{ }^{\circ} \mathrm{C}$ for $10 \mathrm{~min}$, then poured onto nutrient agar (Scharlau) plates. Several colonies appeared after 2 days incubation; these were tested for xylanase activity on nutrient agar plates containing $0.4 \%(\mathrm{w} / \mathrm{v})$ xylan. Of the colonies that formed clear haloes of xylan degradation, strain $\mathrm{BP}-23^{\mathrm{T}}$ was selected for further studies (Blanco \& Pastor, 1993). The following reference strains were used in the study: Paenibacillus illinoisensis DSM $11733^{\mathrm{T}}$, Paenibacillus pabuli DSM $3036^{\mathrm{T}}$ and Paenibacillus amylolyticus DSM $15211^{\mathrm{T}}$. All strains were grown on nutrient broth

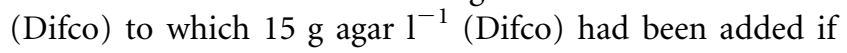
needed.

Cell morphology and the shape of the spores were examined by phase-contrast microscopy (BX40 microscope; Olympus) using cells grown for 2 days at $30^{\circ} \mathrm{C}$ on nutrient agar containing $0 \cdot 1 \%(\mathrm{w} / \mathrm{v}) \mathrm{MnSO}_{4}$. The sizes of cells and swollen sporangia were analysed on a Hitachi H600 AB transmission electron microscope at an operating voltage of $100 \mathrm{kV}$, using cells stained with $2 \%(\mathrm{v} / \mathrm{v})$ glutaraldehyde and $1 \%(\mathrm{w} / \mathrm{v}) \mathrm{OsO}_{4}$ and $0.8 \%(\mathrm{w} / \mathrm{v}) \mathrm{FeCNK}$ in $0 \cdot 1 \mathrm{M}$ 
phosphate buffer. The biochemical properties of strains grown on nutrient agar were determined as described previously (Gordon et al., 1973; Claus \& Berkeley, 1986) and by using API $50 \mathrm{CH}$ tests (bioMérieux). Respiratory quinones and polar lipids were analysed as described by Tindall (1990). The cellular fatty acid content was analysed by using the method described by Kucheryava et al. (1999).

Genomic DNA extraction, PCR-mediated amplification of the 16S rRNA gene and purification of PCR products were carried out as described previously (Rainey et al., 1996). Purified PCR products were sequenced using the CEQ DTCS Quick Start kit (Beckman Coulter) according to the manufacturer's protocol. Sequence reactions were electrophoresed using the CEQ 8000 genetic analysis system (Beckman Coulter). The ae2 editor (Maidak et al., 1999) was used to align the 16S rRNA gene sequence determined in this study against those of representatives of the main bacterial lineages available from the public databases. Pairwise evolutionary distances were computed by using the correction of Jukes \& Cantor (1969). A dendrogram was reconstructed from a distance matrix by using the treeing algorithm of De Soete (1983) and Felsenstein (1993).

Fully automated ribotyping of EcoRI-digested samples was performed with a RiboPrinter system (DuPont Qualicon) as described by Bruce (1996). Images of hybridization were analysed according to Barney et al. (2001). DNA was isolated using a French pressure cell (Thermo Spectronic) and was purified by chromatography on hydroxyapatite as described by Cashion et al. (1977).

DNA-DNA hybridization was carried out as described by De Ley et al. (1970), with the modifications described by Huß et al. (1983) and Escara \& Hutton (1980), using a model 2600 spectrophotometer equipped with a model 2527-R thermoprogrammer and plotter (Gilford Instrument Laboratories). Renaturation rates were computed with the TRANSFER.BAS program of Jahnke (1992).

The $\mathrm{G}+\mathrm{C}$ content of the DNA was determined according to Mesbah et al. (1989) and Tamaoka \& Komagata (1984). DNA was enzymically hydrolysed and dephosphorylated, and the resultant nucleosides were analysed by HPLC.

In a previous study, strain $\mathrm{BP}-23^{\mathrm{T}}$ had been preliminarily assigned to the genus Bacillus (Blanco \& Pastor, 1993). The strain was selected as a high-level producer of xylanase in media supplemented with rice straw, demonstrating the presence of a complex enzyme system for xylan degradation (Blanco et al., 1995, 1999; Gallardo et al., 2003). Colonies of strain $\mathrm{BP}-23^{\mathrm{T}}$ were circular to slightly irregular, pale yellow in colour and $0.5 \mathrm{~mm}$ in diameter after growth for $48 \mathrm{~h}$ at $30^{\circ} \mathrm{C}$ and $\mathrm{pH} 7 \cdot 0$ in nutrient broth. The cells of strain BP$23^{\mathrm{T}}$ were rod-shaped, measuring $0 \cdot 5-1 \times 1 \cdot 5-4.5 \mu \mathrm{m}$, and produced ellipsoidal endospores in swollen sporangia at a subterminal position (see the supplementary figure available in IJSEM Online). The phenotypic properties of strain BP$23^{\mathrm{T}}$ are summarized in Table 1.
Table 1. Phenotypic properties of strain $B P-23^{\top}$ and closely related Paenibacillus species

Strains: 1, P. barcinonensis BP-23 ${ }^{\mathrm{T}} ; 2$, P. pabuli DSM $3036^{\mathrm{T}} ; 3, P$. illinoisensis DSM $11733^{\mathrm{T}}$; 4, P. amylolyticus DSM $15211^{\mathrm{T}}$. All of the strains are Gram-positive, catalase-positive, grow in the presence of $2 \%(\mathrm{w} / \mathrm{v}) \mathrm{NaCl}$, hydrolyse gelatin and produce acid from glucose, D-xylose, L-arabinose and mannitol. None of the strains produces acetylmethylcarbinol, utilizes citrate or produces acid from sorbitol. Symbols: +, positive; -, negative; ND, not determined.

\begin{tabular}{|lcccc|}
\hline Test & $\mathbf{1}$ & $\mathbf{2}$ & $\mathbf{3}$ & $\mathbf{4}^{*}$ \\
\hline Anaerobic growth & + & + & - & + \\
Oxidase & - & + & + & - \\
pH in Voges-Proskauer broth & $4 \cdot 7$ & $4 \cdot 7$ & $4 \cdot 7$ & $5 \cdot 2$ \\
Maximum growth temp. & 40 & 40 & $45 \dagger$ & 40 \\
Minimum growth temp. & 10 & $\mathrm{ND}$ & $\mathrm{ND}$ & 10 \\
Growth in the presence of: & & & & \\
$\quad$ NaCl at 5\% (w/v) & + & + & - & - \\
Lysozyme at 0.001\% (w/v) & + & + & - & - \\
Nitrate reduction & - & + & - & + \\
Urease & - & - & - & $\mathrm{ND}$ \\
Hydrolysis of: & & & & \\
$\quad$ Starch & - & + & + & + \\
Casein & - & - & + & + \\
Utilization of propionate & - & $\mathrm{ND}$ & - & - \\
Acid from: & & & & \\
$\quad$ Rhamnose & - & + & + & - \\
Lactose & + & + & + & - \\
D-Raffinose & + & + & + & - \\
\end{tabular}

${ }^{\star}$ Data from Shida et al. (1997b).

†Weak growth.

Chemotaxonomic characterization showed that the major isoprenoid quinone was MK-7, which is the major menaquinone generally found in aerobic endospore-forming rods. The major polar lipids present were diphosphatidylglycerol, phosphatidylethanolamine and two amino-positive phospholipids that could not be identified. Only traces of phosphatidylglycerol could be detected. The cellular fatty acid profile of strain BP- $23^{\mathrm{T}}$ showed anteiso- $\mathrm{C}_{15: 0}$ to be the predominant fatty acid $(37 \cdot 24 \%)$; this is similar to the situation for members of the genus Paenibacillus (Kämpfer, 2002). The other major fatty acids were $\mathrm{C}_{16: 1} \omega 11 \mathrm{c}$ $(15 \cdot 22 \%)$, iso- $\mathrm{C}_{15: 0}(11 \cdot 62 \%)$ and $\mathrm{C}_{16: 0}(11 \cdot 45 \%)$.

The almost-complete sequence of the $16 \mathrm{~S}$ rRNA gene of strain BP- $23^{\mathrm{T}}$ was determined: it comprised $1523 \mathrm{nt}$ ranging from position $32\left(5^{\prime}\right)$ to $1541\left(3^{\prime}\right)$ according to Escherichia coli numbering (Brosius et al., 1978). Comparison of 1150 unambiguous nucleotides between positions 45 and 1390 showed that the strain fell within the radiation of the genus Paenibacillus and represented a distinct lineage within the genus (Fig. 1; see also the extended tree available as a supplementary figure in IJSEM 


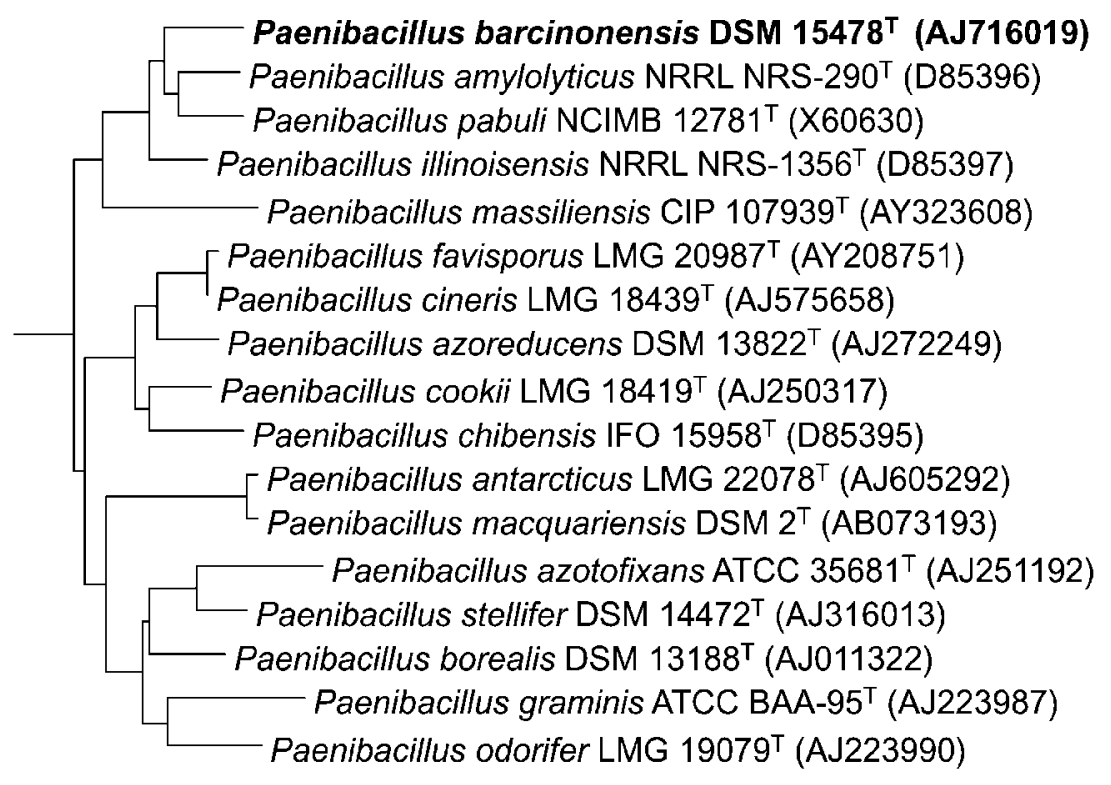

$5 \%$
Fig. 1. Neighbour-joining tree showing similarity of the 16S rRNA gene sequence of strain $B P-23^{\top}$ to those of species of the genus Paenibacillus. Sequences of members of the Bacillus/Staphylococcus group were used to root the dendrogram. The strain designations and GenBank/EMBL/DDBJ accession numbers for the $16 \mathrm{~S}$ rRNA gene sequences of the reference strains used are indicated. Bar, 5 nucleotide substitutions per 100 nucleotides.
Online). The highest levels of 16S rRNA gene sequence similarity were found with respect to $P$. illinoisensis (GenBank/EMBL/DDBJ accession no. D85397), P. pabuli (X60630) and P. amylolyticus (D85396), the values being $97 \cdot 4,97 \cdot 1$ and $96 \cdot 9 \%$, respectively. Ribotyping was performed with strain $\mathrm{BP}-23^{\mathrm{T}}$ and species with highly similar $16 \mathrm{~S}$ rRNA gene sequences (Fig. 2). Strain BP- $23^{\mathrm{T}}$ generated a ribofragment pattern that was clearly different from those of closely related species such as P. illinoisensis, P. pabuli and $P$. amylolyticus. DNA-DNA hybridization was performed to determine the genomic relatedness between strain $\mathrm{BP}-23^{\mathrm{T}}$ and $P$. illinoisensis, $P$. pabuli and P. amylolyticus, the species with the highest levels of $16 \mathrm{~S}$ rRNA gene

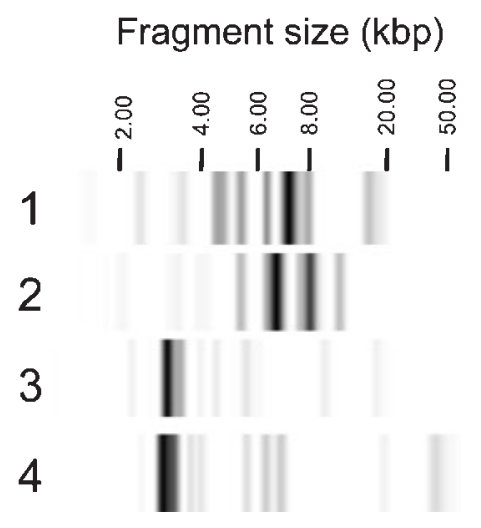

Fig. 2. RiboPrint patterns of strain $B P-23^{\top}$ and three Paenibacillus type strains generated by digestion of genomic DNA using the restriction enzyme EcoRl. Strains: 1, $P$. pabuli DSM $3036^{\top} ; 2$, P. amylolyticus DSM $15211^{\top} ; 3, P$. barcinonensis $\mathrm{BP}-23^{\mathrm{T}} ; 4$, P. illinoisensis DSM $11733^{\mathrm{T}}$. sequence similarity to the strain. Strain $\mathrm{BP}-23^{\mathrm{T}}$ exhibited reassociation values of $32 \cdot 7,31 \cdot 6$ and $23 \cdot 0 \%$, respectively, with respect to the aforementioned species, indicating that it is not related to them at the species level (Wayne et al., 1987). The DNA G+C content of strain $\mathrm{BP}-23^{\mathrm{T}}$ was $45.0 \mathrm{~mol} \%$, which lies within the range observed for members of the genus Paenibacillus (Shida et al., 1997a).

On the basis of the above results, it was concluded that strain $\mathrm{BP}-23^{\mathrm{T}}$ represents a novel species of Paenibacillus, for which the name Paenibacillus barcinonensis sp. nov. is proposed. Strain $\mathrm{BP}-23^{\mathrm{T}}$ currently constitutes the only strain of this novel species and is the type strain.

\section{Description of Paenibacillus barcinonensis sp. nov.}

Paenibacillus barcinonensis (bar.ci.no.nen'sis. L. masc. adj. barcinonensis from Barcino, the Roman name for Barcelona, the city in Spain where the strain was isolated).

Gram-positive, facultatively anaerobic rods $(0 \cdot 5-1 \times 1 \cdot 5-$ $4 \cdot 5 \mu \mathrm{m})$. Ellipsoidal endospores form in swollen sporangia at a subterminal position. Colonies are circular to slightly irregular, pale yellow in colour and $0.5 \mathrm{~mm}$ in diameter after 2 days growth at $30^{\circ} \mathrm{C}$ in nutrient broth. Growth occurs at temperatures in the range $10-40^{\circ} \mathrm{C}$. Growth occurs at $\mathrm{pH} 5 \cdot 0-10 \cdot 4$. Growth occurs in the presence of $5 \%(\mathrm{w} / \mathrm{v}) \mathrm{NaCl}$ and $0.001 \%(\mathrm{w} / \mathrm{v})$ lysozyme. Catalasepositive. Oxidase- and urease-negative. Nitrate is not reduced to nitrite or nitrogen. Acetylmethylcarbinol is not produced. The $\mathrm{pH}$ in Voges-Proskauer broth is $4 \cdot 7$. Gelatin is hydrolysed. Casein and starch are not hydrolysed. Citrate and propionate are not utilized. Acid is produced from glycerol, D-arabinose, L-arabinose, ribose, D-xylose, 
methyl $\beta$-xyloside, galactose, D-glucose, D-fructose, D-mannose, mannitol, $N$-acetylglucosamine, amygdalin, arbutin, aesculin, salicin, cellobiose, maltose, lactose, melibiose, sucrose, trehalose, D-raffinose, $\beta$-gentiobiose, $D$-turanose and gluconate. Acid is not produced from erythritol, L-xylose, adonitol, L-sorbose, rhamnose, dulcitol, inositol, sorbitol, methyl $\alpha$-D-mannoside, methyl $\alpha$-Dglucoside, inulin, melezitose, starch, glycogen, xylitol, Dlyxose, D-tagatose, D-fucose, L-fucose, D-arabitol, L-arabitol, 2-ketogluconate or 5-ketogluconate. The major fatty acids are anteiso- $\mathrm{C}_{15: 0}, \mathrm{C}_{16: 1} \omega 11 c$, iso- $\mathrm{C}_{15: 0}$ and $\mathrm{C}_{16: 0}$. The predominant menaquinone is MK-7. The major polar lipids present are diphosphatidylglycerol, phosphatidylethanolamine and two unidentified amino-phospholipids. The DNA G $+\mathrm{C}$ content is $45 \cdot 0 \mathrm{~mol} \%$.

Isolated from soil from a rice field in the Ebro River delta, Spain. The type strain is $\mathrm{BP}-23^{\mathrm{T}}\left(=\mathrm{CECT} 7022^{\mathrm{T}}=\mathrm{DSM}\right.$ $\left.15478^{\mathrm{T}}\right)$.

\section{Acknowledgements}

We thank Serveis Científico-Tècnics of the University of Barcelona for their support with transmission electron microscopy. This work was partially supported by the Spanish Ministry of Science and Technology (CICYT), projects QUI98-0413-CO2-02 and PPQ2001-2161-CO2-02. M.M.S. held an FPI grant from the Spanish Ministry of Science and Technology and a short-term grant from the DSMZ.

\section{References}

Ash, C., Farrow, J. A. E., Wallbanks, S. \& Collins, M. D. (1991). Phylogenetic heterogeneity of the genus Bacillus revealed by comparative analysis of small subunit ribosomal RNA sequences. Lett Appl Microbiol 13, 202-206.

Ash, C., Priest, F. G. \& Collins, M. D. (1993). Molecular identification of rRNA group 3 bacilli (Ash, Farrow, Wallbanks and Collins) using a PCR probe. Proposal for the creation of a new genus Paenibacillus. Antonie van Leeuwenhoek 64, 253-260.

Barney, M., Volgyi, A., Navarro, A. \& Ryder, D. (2001). Riboprinting and $16 \mathrm{~S}$ rRNA gene sequencing for identification of brewery Pediococcus isolates. Appl Environ Microbiol 67, 553-560.

Berge, O., Guinebretière, M. H., Achouak, W., Normand, P. \& Heulin, T. (2002). Paenibacillus graminis sp. nov. and Paenibacillus odorifer sp. nov., isolated from plant roots, soil and food. Int J Syst Evol Microbiol 52, 607-616.

Blanco, A. \& Pastor, F. I. J. (1993). Characterization of cellulase-free xylanases from the newly isolated Bacillus sp. strain BP-23. Can J Microbiol 39, 1162-1166.

Blanco, A., Vidal, T., Colom, J. F. \& Pastor, F. I. J. (1995). Purification and properties of xylanase A from alkali-tolerant Bacillus sp. strain BP-23. Appl Environ Microbiol 61, 4468-4470.

Blanco, A., Díaz, P., Zueco, J., Parascandola, P. \& Pastor, F. I. J. (1999). A multidomain xylanase from a Bacillus sp. with a region homologous to thermostabilizing domains of thermophilic enzymes. Microbiology 145, 2163-2170.

Brosius, J., Palmer, M. L., Kennedy, P. J. \& Noller, H. F. (1978). Complete nucleotide sequence of a $16 \mathrm{~S}$ ribosomal RNA gene from Escherichia coli. Proc Natl Acad Sci U S A 75, 4801-4805.

Bruce, J. (1996). Automated system rapidly identifies and characterizes microorganisms in food. Food Technol 50, 77-81.
Cashion, P., Hodler-Franklin, M. A., McCully, J. \& Franklin, M. (1977). A rapid method for base ratio determination of bacterial DNA. Anal Biochem 81, 461-466.

Claus, D. \& Berkeley, R. C. W. (1986). Genus Bacillus Cohn 1872, $174^{\mathrm{AL}}$. In Bergey's Manual of Systematic Bacteriology, vol. 2, pp. 1105-1139. Edited by P. H. A. Sneath, N. S. Mair, M. E. Sharpe \& J. G. Holt. Baltimore: Williams \& Wilkins.

De Ley, J., Cattoir, H. \& Reynaerts, A. (1970). The quantitative measurement of DNA hybridization from renaturation rates. Eur J Biochem 12, 133-142.

De Soete, G. (1983). A least squares algorithm for fitting additive trees to proximity data. Psychometrika 48, 621-626.

Escara, J. F. \& Hutton, J. R. (1980). Thermal stability and renaturation of DNA in dimethyl sulfoxide solutions: acceleration of renaturation rate. Biopolymers 19, 1315-1327.

Felsenstein, J. (1993). PHYLIP (phylogeny inference package), version 3.5.1. Department of Genetics, University of Washington, Seattle, USA.

Gallardo, O., Diaz, P. \& Pastor, F. I. J. (2003). Characterization of a Paenibacillus cell-associated xylanase with high activity on arylxylosides: a new subclass of family 10 xylanases. Appl Microbiol Biotechnol 61, 226-233.

Gordon, R. E., Haynes, W. C. \& Pang, C. H. (1973). The Genus Bacillus, handbook no. 427. Washington, DC: US Department of Agriculture.

Huß, V. A. R., Festl, H. \& Schleifer, K. H. (1983). Studies on the spectrophotometric determination of DNA hybridization from renaturation rates. Syst Appl Microbiol 4, 184-192.

Jahnke, K. D. (1992). Basic computer program for evaluation of spectroscopic DNA renaturation data from GILFORD system 2600 spectrometer on a PC/XT/AT type personal computer. J Microbiol Methods 15, 61-73.

Jukes, T. H. \& Cantor, C. R. (1969). Evolution of protein molecules. In Mammalian Protein Metabolism, pp. 21-132. Edited by H. N. Munro. New York: Academic Press.

Kämpfer, P. (2002). Whole-cell fatty acid analysis in the systematics of Bacillus and related genera. In Applications and Systematics of Bacillus and Relatives, pp. 271-299. Edited by R. Berkeley, M. Heyndrickx, N. Logan \& P. De Vos. Oxford: Blackwell.

Kucheryava, N., Fiss, M., Auling, G. \& Kroppenstedt, R. M. (1999). Isolation and characterization of epiphytic bacteria from the phyllosphere of apple, antagonistic in vitro to Venturia inaequalis, the causal agent of apple scab. Syst Appl Microbiol 22, 472-478.

Maidak, B. L., Cole, J. R., Parker, C. T., Jr \& 11 other authors (1999). A new version of the RDP (Ribosomal Database Project). Nucleic Acids Res 27, 171-173.

Mesbah, M., Premachandran, U. \& Whitman, W. B. (1989). Precise measurement of the $\mathrm{G}+\mathrm{C}$ content of deoxyribonucleic acid by highperformance liquid chromatography. Int J Syst Bacteriol 39, 159-167.

Outtrup, H. \& Jørgensen, S. T. (2002). The importance of Bacillus species in the production of industrial enzymes. In Applications and Systematics of Bacillus and Relatives, pp. 206-218. Edited by R. Berkeley, M. Heyndrickx, N. Logan \& P. De Vos. Oxford: Blackwell.

Rainey, F. A., Ward-Rainey, N., Kroppenstedt, R. M. \& Stackebrandt, E. (1996). The genus Nocardiopsis represents a phylogenetically coherent taxon and a distinct actinomycete lineage: proposal of Nocardiopsaceae fam. nov. Int J Syst Bacteriol 46, 1088-1092.

Shida, O., Takagi, H., Kadowaki, K., Nakamura, L. K. \& Komagata, K. (1997a). Transfer of Bacillus alginolyticus, Bacillus chondroitinus, Bacillus curdlanolyticus, Bacillus glucanolyticus, Bacillus kobensis, and Bacillus thiaminolyticus to the genus Paenibacillus and emended description of the genus Paenibacillus. Int J Syst Bacteriol 47, 289-298. 
Shida, O., Takagi, H., Kadowaki, K., Nakamura, L. K. \& Komagata, K. (1997b). Emended description of Paenibacillus amylolyticus and description of Paenibacillus illinoisensis sp. nov. and Paenibacillus chibensis sp. nov. Int J Syst Bacteriol 47, 299-306.

Tamaoka, J. \& Komagata, K. (1984). Determination of DNA base composition by reversed-phase high-performance liquid chromatography. FEMS Microbiol Lett 25, 125-128.
Tindall, B. J. (1990). A comparative study of the lipid composition of Halobacterium saccharovorum from various sources. Syst Appl Microbiol 13, 128-130.

Wayne, L. G., Brenner, D. J., Colwell, R. R. \& 9 other authors (1987). International Committee on Systematic Bacteriology. Report of the ad hoc committee on reconciliation of approaches to bacterial systematics. Int J Syst Bacteriol 37, 463-464. 